\title{
The Comparison between the Eastern and Western Management Ideas
}

\author{
Yaling Li \\ Business and Tourism Management School \\ Yunnan University \\ Kunming, China
}

\begin{abstract}
East and western management ideas have their own characteristics and advantages, which are closely related to the different philosophical backgrounds and social and cultural backgrounds. The main differences between Eastern and western management ideas lie in the different management tools using in the specific management practice, the different social and cultural background of management ideas and the methods to solve the problem of the specific management. The Oriental management ideas tend to be emotional, whereas western management thoughts tend to be rational. Despite of the differences, eastern and western management ideas are essentially consistent, which is an important basis for the integration of eastern and western management ideas.
\end{abstract}

Keywords-management ideas; management practice; comparison

\section{INTRODUCTION}

Oriental management theory originated from the excellent traditional culture of the orient. China and Japan are the representative of Oriental management ideas, the main feature is based on China traditional culture, use many thinking modes of philosophy, carry out mainly humanistic thought, also emphasize organizational culture, harmony relationship, closely connection and strong sense of community. At a process of decision making, the decision of decision maker made a big difference for the process, explicitly subjective.

The philosophy of western management originated from the philosophy of ancient Greece. In addition to the deep philosophical origin of ancient Greece, it is more important to rely on the development of science and technology since modern times. Western management scholars have been looking for the innovation and breakthrough of the management model with the process of continuous economic change and formed the western management theory, which was based on the theoretical foundation and practical experience. It was generally accepted by the academic circles that the western management begin with classical management theory of Taylor, which was based on the hypothesis of "economic man", valuing things rather than people, People are only regarded as tools to realize economic benefits, and then western management has developed into the behavioral science management theory represented by Mayo and Maslow. The theory began to focus on the role of human psychological factors in management, so it was based on the hypothesis of "social man" and researched the potential impact of human emotional factors on economic activities through numerous experiments. After the behavioral science management theory, because the western economy developed rapidly, the economic environment was complex and changeable, the management theory appeared new development, finally developed to the modern western management science.

View from the development of eastern and western management thought, due to the different social and cultural background, there are differences between the two. Each has its own merits and demerits.

The requirements of economic globalization and the development of international trade make enterprises pay more and more attention to overseas market development Economies and trade permeate each other within countries, and the world as a whole is becoming more and more interconnected. The development of Oriental enterprises needs the support of the western market. The development of western enterprises also requires the support of the Oriental market.

An increasing number of east and west companies are building subsidiaries in each other's countries to open up new markets. In such a situation like this, the implementation of the management also gradually globalization. How to manage the staffs from different nationalities, different cultural background, and how to establish effective management system in foreign special cultural background and legal system are gradually become an important proposition in the development of management. The proper use of management ideas directly affects the development of the organization.

However, because the inherent defects of eastern and western management thoughts system cannot overcome these defects on its own system, and the inherent defect will greatly affect the further development of eastern and western management ideas. This requires the eastern and western management theory study the core content of management thoughts of each other constantly, absorb the essence of each other, adapt to each other's thinking system, constantly update their management thoughts and theories according to the different market environment to adapt to the new market 
background. In the context of economic globalization, the development of foreign markets and the pursuit of profit make the reference and integration of east and west management ideas inevitable.

Despite of the differences, eastern and western management ideas are essentially consistent, which is an important basis for the integration of eastern and western management ideas.

\section{THE DIFFERENCES BETWEEN EASTERN AND WESTERN MANAGEMENT THOUGHTS}

\section{A. The Characteristics of Eastern Management Thought}

The oriental management thought is based on human's natural thinking mode and logic, mainly based on the core values such as humanism, harmony, the view of the mean and the view of justice and profit.

First, it emphasizes the human-centered idea of "management as the center". Throughout the ages, Chinese thinkers and politicians have attached great importance to the human factor, they believe that social stability and the strength of the country depend on people. Mencius said, "the people are the most expensive, the state is the second, and the king is light." Confucius said, "the ruler, the boat, the common man, the water, and the water can carry the boat, also can submerged it." At all times and in all over the world, only Chinese management culture has raised the status and importance of people in management to such a high level.

Second, it emphasizes harmony and stability, and pays more attention to "human relations" and "relationships." "He" is one of the most typical and basic categories in Chinese traditional culture, and it has always been the guideline to guide people to deal with the relationship between people. It is an important feature of Chinese management culture that the strength of modern enterprises' competitiveness depends largely on the internal coordination and harmony. In addition, the oriental management ideology seeks stability, not change and innovation.

Third, it is emphasized that the best way to deal with the problem is the mean, with less friction and direct conflict in the organization.

Fourth, the relationship between "justice" and "benefit" should be handled well. It is of great practical significance to the development of management practice. "the view of justice and benefit" means that people should not abandon the principle of "justice" while pursuing their interests, that is, management should take into account "justice" and "interest", and "righteousness" as the first. In short, it is a gentleman who loves money, take the way.

Fifth, emphasizing the exertion and mobilization of the subjective initiative of people, pay attention to the coordination and balance of various management factors, social weight, emphasis on sensibility, fuzzy analysis, "chaos management"; It is a kind of "soft" management thought to be good at using stratagem as the communication center in the strategic thought.

\section{B. The Characteristic of the Western Management Thought}

The western management science is from the management science. Behavioral science and contingency management thought, the emphasis of modern management thoughts is to improve productivity. According to the market and macro environment to create higher profits. It eventually formed a complete system after Taylor put forward the theory of scientific management. Therefore, the main characteristics of western management is scientific and standardized, Institutionalization, qualitatively and quantitatively analysis of specific issues, decision-making in accordance with a certain process and steps, the system is perfect, the relationship between the members of the organization is relatively indifferent, highlighting the role and ability of the individual, clear powers and responsibilities, clear rewards and penalties, represented by the Anglo-American countries.

First, the Western management thinking to efficiency, profit as the starting point, with the system and process to restrict each member of the organization. Improve the efficiency of the whole organization as scientifically as possible. The whole organization is like a well-designed machine, and each member is like a part of the machine, running in a fixed way according to the designed trajectory. To ensure the best efficiency and the highest profit.

Second, the western traditional culture pays more attention to rationality, and its management emphasizes the premise of goal, restrict and standardize the management by legal means, which makes western management have a strong precaution.

Third, the western management ideology is more scientific, more emphasis on rationality, quantitative analysis, the West is good at using the latest achievements of science and technology, through experiments and logical analysis, strict control and management. Is a kind of "hard" management thought.

Fourth, the formation and development of management idea are more integrated. It use a large number of modern economics, sociology, psychology and political science and other aspects of research results to develop their own theory; Especially the development and popularization of computer technology play a role in the development of management theory. The development of computer and information technology has changed people's work, study and life. It also has changed the speed and mode of management theory.

Fifth, the western nation dared to take risks, advocating breakthrough and innovation, which was manifested by the western countries paying attention to the introduction of competition mechanism in the management, improving the efficiency of the whole management activity, and constantly reforming and innovating the management theory according to the result of practice.

Sixth, the western management thought took the material as the foundation, regarded the human as the tool to obtain the economic benefit, ignored the human emotion and other psychological factors. The most obvious manifestation was in the era of "economic man" in Taylor. Although the 
western management thought gradually approached the idea of "people-oriented" in the later stage, it strengthened the study of human beings. But there is still one kind to attach importance to people's non-consciousness, which cannot be compared with the oriental management thought that emphasizes people first in essence.

\section{REASONS FOR THE DIFFERENCES IN MANAGEMENT THOUGHT BETWEEN THE EAST AND THE WEST}

Under the influence of the specific environment, the formed management thought also has the very big difference, according to the elaborations of scholar to the difference origin of Chinese and the western management thought, the difference between the two mainly comes from three aspects: the geographical environment, The cultural origin, and the development background.

\section{A. Geographical Environment Factors}

The East and the West are located in different geographical locations. The birthplace of Oriental culture is the mainland, which is based on agriculture, it is easy to satisfy, and seeks to live and work, so the personalities of the Orientals are conservative and steady. China is a country mainly based on mainland, with inconvenient external traffic, and influenced by the thoughts of highly centralized, the management emphasized the holistic management in macrolevel. The "political" of China management culture and "cultivating oneself, putting family in order, ruling the country, pacifying the land" of the Confucianism mentioned by Dong jingbao and Wang shangyi in 《The analysis of Chinese and western management idea culture $\rangle$, which are carry out in country aspect; This is also true of the concept of" governing the country" put forward by the thinker Wang fuzhi and others in the late Ming and early Qing dynasties; Military management and war also serve political rule; economic development is also consolidate political rule. Political nature reflects the center of the "state". This is closely related to the background of Chinese feudal society. The ancient dynasties of china are constantly changing. If a kind of ideological and theoretical system wants to stand out from many doctrines, it must meet the needs of rulers. So the essence of Oriental management ideas is the center of state.

However, the western culture originated in the sea, which can expand across the ocean, develop business, so the Westerners love to take risks and dare to innovate. Western countries and regions are mostly adjacent to the sea, external and internal traffic is developed. And it continues to expand the external, management focuses on the micro-level management.

\section{B. The Root Factors of Culture}

Management is the crystallization of culture. Management is the crystallization of culture, and the specific management thought implies in the specific cultural tradition dominates and influences, thus it carries the specific cultural tradition characteristic and the brand. From the differences between Chinese and Western cultural traditions, we can see the differences between Chinese and Western management thoughts.

Under the influence of social history and culture, China is based on agriculture, emphasizing stability, coordination and balance in management, while the west is based on business, without a unified management thought to lead the management of the whole western enterprises.

In the traditional ideological and cultural accumulation, Chinese Confucianism and culture have an extremely important impact on the management culture of the Chinese nation, while the West is partial to the management thought style of "freedom, equality and fraternity" advocated by capitalism.

The Oriental culture centered on Confucianism of ethic emphasizes irrational way of thinking, and permeated with the characteristics of implicitness, humanistic concern, neutralization and group. While the western culture, which is based on the rational spirit of modern science, emphasizes on the analytical thinking, and confirms the calibration, the accuracy of the quantity, the discrimination of the experiment and the authority of the rationality of the widely prevailing experience in science. Take the principles of science as the principles of social life.

\section{The Development Background}

On the one hand, China's present management thought originated from the ancient management of the Spring and Autumn period and the warring states period. On the other hand, it is the result by studying and drawing lessons from Western management thoughts in the near future.

\section{ADVANTAGES AND DISADVANTAGES OF EASTERN AND WESTERN MANAGEMENT IDEAS}

Any kind of theory has some limitation of time and space, no matter the management thought of the east or the west has its advantages. Comparing the advantages and disadvantages of Chinese and western management, it is convenient for us to understand the applicability and limitation of Chinese and western management thought deeply.

\section{A. The Advantages and Disadvantages of Oriental Management Thought}

Oriental management thought is based on Chinese traditional humanistic culture, which is good at coordinating interpersonal relationship and pursuing group harmony. The relationship and atmosphere of the group, the position and function of the people in the group are very important. However, in the oriental management thought, the relationship, harmony, human relations and other factors are too important to sacrifice the efficiency of the organization. And the trend of collectivism is extremely easy to suppress people's enthusiasm and creativity.

Oriental management culture has a deep foundation, and its advantages are to emphasize harmony, stability and team consciousness, which is conducive to avoiding conflicts within the organization and plays an important role in better optimizing the allocation of resources. However, the 
management of the East is more emphasis on the rule of man than the rule of law, so there is a lack of unified standards in the work of enterprises, and the so-called "egalitarianism" is not conducive to people's competition. It hinders the enthusiasm of employees.

The East emphasizes the soft restraint of morality and the influence of the manager's personality charm. Su Dongshui put forward the idea that "morality is the first" in the oriental management thought. "taking virtue as the first" stresses the morality and the conduct of the gentleman in the world. The words of the Gentleman. The emphasis is on using morality to manage and restrain the behavior of human beings. However, the binding force of morality is obviously insufficient, the moral is illusory and vague, and the definition of morality is not clear up to now. Moreover, it is the basis of management. Therefore, this management idea can easily lead to management failure and even lead to tragedy.

The traditional Chinese management thought emphasizes exerting and mobilizing the active role of people, pays attention to the coordination and balance of various management factors, and is good at deciding all kinds of management measures from the perspective of the overall long-term management objectives. However, the Chinese traditional management thought is based on the feudal agriculture-oriented thought, which lacks the organic connection with modern industrial production and science and technology, is divorced from the market economy, and does not form a systematic scientific form. The west is good at using the latest achievements of science and technology, strictly controlling and managing by experimentation and logical analysis. At the same time, attention should be paid to introducing competition mechanism, improving the efficiency of whole management activity, and constantly changing and innovating management theory according to the result of practice. However, the West emphasizes rationality too much so that it's usually easy to ignore the factor of human. The thorough logical system analysis of a certain element often leads to partial generalization.

\section{B. The Advantages and Disadvantages of Western Management Thoughts}

The West emphasizes rationality too much so that it's usually easy to ignore the factor of human. The thorough logical system analysis of a certain element often leads to partial generalization.

The west is a society of legal system, which governs the country by law. In enterprises and other organizations, It always all rely on the system. Doing so is conducive to strict discipline, reduce the perversion of favoritism. Therefore, the Western management emphasizes on institutionalization, standardization. And Standardize management with strict rules and regulations, with clear rewards and penalties. But too much emphasis on institutionalization, standardization is likely to lead to lack of culture, lack of sense of belonging among the members of the organization; Too much emphasis on individual capabilities and departmental benefits can easily lead to individual interests and departmental interests exceeding the overall interests and strategic objectives of the organization; Quantitative standards and assessment methods may make the organization and its members eager for quick success, too short-sighted, and ignore the long-term strategy and interests of the organization.

The West advocates individuality and freedom, attaches importance to individual feelings and success in management, but it is easy to lead to self-centered and damage the collective harmony. Many scholars believe that collectivism tends to suppress people's enthusiasm and creativity. Individualism to the extreme is easy to cause selfcenteredness and lack of team consciousness.

The western management thought pursues the utility excessively but easily neglects other aspect factors, although it may obtain the bigger benefits in a certain aspect, easy to cause the overall imbalance and the coordination.

Western management ideas in the management and delegation of authority, relatively guaranteed the credibility and authority of decision-making, they pay attention to personal subjective judgment, it's conducive to saving time, but there are also deficiencies. Individualism in decision making is influenced by individual management ability and experience. Once supervision is weak, personal arbitrariness is easy to come into being.

\section{CONCLUSION}

In a word, whether it is Chinese management, west management, or the combination of east and west management, there is no perfect management theory and mode. In the context of global integration, to meet the needs of scholars and entrepreneurs, the integration of eastern and western management thoughts is increasingly becoming the direction and outlet of the development of oriental management thought and mode in the future.

\section{REFERENCES}

[1] Peter Drucker: management challenges of the 21st Century. [M] .Beijing: mechanical Industry Press, China, 2009.

[2] Jiang Xianrong. A study on the Methodology of Modern Western philosophy of Management. [G]. Beijing: Renmin University of China, 2009.

[3] Du Rong, Cathalta Brugha. The comparison of Eastern and Western Management theories under the Framework of the Theory of thought: exploring the way of the Chinese School of Management Science to the World. [J] .Beijing: Journal of Management, 2017, (10).

[4] Li Ting. A Comparative study of Management Theory and Cultural Management in China and East. [J] .Beijing: modernization of shopping malls, 2012, (22).

[5] Su Yong, Yu Baoping. Oriental Management Research: theoretical Review and Development Direction. [J] .Beijing: Journal of Management, 2009, (6).

[6] Su Dongshui. the trend of East and West Management amalgamation and Development in the 21st Century. [J] .Beijing: Xinhua Abstracts 2009, (1).

[7] Su Dongshui. On Eastern philosophy of Management. [C]. World Management Forum and Oriental Management Forum-the 25th Anniversary of the Shanghai Institute of Management Education, 2006. 